\title{
Defining Marriage, Step One: EGALE V. CANADA
}

\author{
JULIE C. LLOYD ${ }^{*}$
}

\section{INTRODUCTION}

The decision of Justice Pitfield of the Supreme Court of British Columbia in EGALE v. Canada is the first of what is likely to be many decisions on same-sex marriage emerging from Canadian courts in the next few years.

Many interested onlookers assumed that the issue would be resolved under the Canadian Charter of Rights and Freedoms. ${ }^{2}$ The decision, however, considered the application of the Charter only in the alternative. The ratio arose from an interpretation of the Constitution Act, $1867 .^{3}$

\section{THE FACTS}

Seven same-sex couples applied to the Director of Vital Statistics for the Province of British Columbia for a marriage licence. The Marriage $\mathrm{Act}^{4}$ is drafted in gender-neutral terms and contains no express requirement of heterosexuality. The Director declined to issue licences to the petitioners because in his view the federal common law governing the capacity to marry did not include marriage between two persons of the same sex. The couples were joined by Equality for Gays and Lesbians Everywhere ("EGALE") Canada and petitioned the court for declaratory relief and for an order requiring the Director to issue the licences.

\section{THE DECISION}

Justice Pitfield denied the petitioners' application. He found that while the term "marriage" was not defined in any federal statute, the term had been conclusively defined at common law and in the public consciousness prior to the enactment of the Constitution Act, 1867.

That "marriage" had been defined was demonstrated by the House of Lords decision in Hyde v. Hyde and Woodmansee, rendered a few months before Confederation. Heterosexuality was one element of this common law definition, and, accordingly, the term "marriage," as employed in s. 91 of the Constitution Act, 1867 conferred to Parliament the power to legislate in relation to heterosexual marriage alone.

Barrister and Solicitor, Edmonton, Alberta.

EGALE Canada v. Canada (A.G.), [200I] B.C.J. No. 1995 (S.C.), online QL (BCJ).

Canadian Charter of Rights and Freedoms, Part I of the Constitution Act, 1982, being Schedule B to the Canada Act 1982 (U.K.), 1982, c. 11 [hereinafter Charter]. See D. Casswell, “Moving Toward Same Sex Marriage" (2001) 80 Can. Bar Rev. 810 for a helpful analysis of the Charter issues. Constitution Act. 1867 (U.K.), 30 \& 31 Vict., c. 3, reprinted in R.S.C. 1985, App. II, No. 5.

Marriage Act, R.S.B.C. 1996, c. 282.

(1866), L.R. I P. \& D. 130 [hereinafter Hyde]. 
Should Parliament attempt to pass a law enabling (or, presumably, prohibiting) samesex marriage, it would be attempting to alter the meaning of a head of power. This is impermissible, and any such legislation would be ultra vires. Parliament could obtain the jurisdiction to legislate in relation to same-sex marriage only through the process of constitutional amendment. The head of power would have to be amended in a manner that would contemplate Parliament legislating in relation to same-sex marriage:

The relief sought, namely the characterization of same-sex relationships as marriage, cannot be delivered by Parliament under s. 91(26) of the Constitution of Canada without an amendment to the Constitution procured with the agreement of the provinces in the manner contemplated by the Constitution Act, 1982. In my opinion the petitions must be dismissed. ${ }^{6}$

This conclusion pre-empted a Charter analysis because any violation that such an analysis might disclose could not be redressed by Parliament.

I will argue that Pitfield J. did not employ the proper analysis in interpreting the term "marriage" as contained in the Constitution Act, 1867. I will also argue that should his analysis be supported by the jurisprudence, the finding that "marriage" had been unambiguously defined as of 1867 was factually in error. Finally, I will propose an approach to the interpretation of the term "marriage" more consistent with the jurisprudence. A functional and purposive approach to the definition of the term would include "same-sex marriage" within the ambit of the "marriage" head of power and would not exclude same-sex couples from seeking any remedy that might arise under a Charter analysis of their claim.

\section{Marriage and Divorce - A Constitutional Primer}

Section 91(26) of the Constitution Act, 1867 confers to Parliament the authority to legislate in relation to "Marriage and Divorce." Section 92(12) gives provincial legislatures the power to make laws in relation to "the solemnization of marriage in the province." The distinction between these heads of powers was considered in Re Marriage Legislation in Canada. ${ }^{7}$ The federal power includes that of legislating in relation to the essential validity of marriage and the capacity of parties to marry, while the provincial power includes that of legislating the formal validity of marriage and matters touching upon the solemnization of marriage. The division, though stated clearly, does create some complexities in that solemnization powers have been found to include some matters that touch on the validity of the marriage. ${ }^{8}$

Parliament has enacted some legislation touching on issues of marital capacity. The Marriage (Prohibited Degrees) $A c t^{9}$ prohibits marriage between persons on the basis of consanguinity and affinity. There are also provisions in the Criminal Code ${ }^{10}$ prohibiting

Supra note 1 at para. 124.

[1912] A.C. 880, 7 D.L.R. 629.

See ibid.

S.C. 1990 , c. 46.

R.S.C. 1985, c. C-46, ss. 290-91, 293. 
polygamy and bigamy. No Canadian act defines marriage or sets out the elements of marital capacity.

\section{PRinCiples of CONSTITUTIONAL INTERPRETATION - EDWARDS V. A.G. (CANADA)}

Edwards v. Canada (A.G.) $)^{11}$ is a jurisprudential cornerstone of the principles by which the Constitution Act, 1867 is to be interpreted. The decision in Edwards created a powerful and enduring image of Canada's constituting documents: "The British North America Act planted in Canada a living tree capable of growth and expansion."'2

Justice Pitfield distinguishes the Privy Council decision in Edwards:

In Edwards the Privy Council observed that there was ambiguity surrounding the question of which persons could serve as senators. The general words "banking," "criminal law," "inter-provincial undertaking" and "direct taxation within the province" are equally ambiguous. The general nature of the words has permitted flexibility and fluid interpretation in order to give effect to the Constitution as the needs of Canadian society have changed over the years. ${ }^{13}$

Marriage, he concludes, is different: "The meaning and legal character of the word [marriage] are not ambiguous."14 The image drawn in Edwards - of a sapling, strong but lithe, leaves still sticky with new growth - is altered by this analysis. The sapling now has, among its eternal newness, one lone branch extended, heavy and fully formed.

Edwards and its imagery, however, is not so easily avoided. The facts and the issues underlying that decision bear a striking similarity to those in this case. In Edwards the Supreme Court of Canada had found that the term "person" employed in s. 24 the Constitution Act, 1867 could include only men, not women, and accordingly women could not be appointed to the Senate. The Court noted that women were disqualified at common law from holding public office and did not have the right to vote under different statutes. Historically, legislation and jurisprudence had consistently excluded women from basic rights of political participation. The term "person" contained in s. 24 could, in the result, include only men.

The Privy Council acknowledged this pedigree of exclusion but declined to find that history tied the hands of constitutional interpretation: "Customs are apt to develop into traditions which are stronger than law and remain unchallenged long after the reason for them has disappeared. The appeal to history therefore in this particular matter is not conclusive."' Further, the intention and nature of constitutional documents demand a different analysis than might be applied to another statute. The Privy Council cites with approval the following observation: "The [B.N.A.] Act should be on all occasions

[1930] A.C. 124, I D.L.R. 98 [hereinafter Edwards].

lbid. at 136.

Supra note 1 at para. 109.

Ibid. at para. 110.

Supra note 11 at 134. 
interpreted in a large, liberal, and comprehensive spirit, considering the magnitude of the subjects with which it purports to deal in very few words." It also adds, "[t]heir Lordships do not conceive it to be the duty of this Board - it is certainly not their desire - to cut down the provisions of the Act by a narrow and technical construction, but rather to give it a large and liberal interpretation."16

Dealing directly with the jurisprudential history of the exclusion of women from rights to participate in the political process, the Privy Council speaks to the place of history in constitutional interpretation:

[T]heir Lordships do not think it right to apply rigidly to Canada of to-day the decisions and the reasonings therefor which commended themselves, probably rightly, to those who had to apply the law in different circumstances, in different centuries, to countries in different stages of development.... [T]his Board must take great care therefore not to interpret legislation meant to apply to one community by a rigid adherence to the customs and traditions of another. ${ }^{17}$

The Privy Council states that when interpreting terms contained in a constitutional document, one must take the perspective of the present and not the past. The Edwards analysis has been employed and developed by the courts in Canada since 1930. Peter Hogg identifies this analytical approach as the doctrine of "progressive interpretation." The doctrine, Hogg describes, is one of the means by which the Constitution Act, 1867 has been able to adapt to changes in Canadian society. The doctrine stipulates that the general language used to describe the classes of subjects (or heads of power) is not to be frozen in the sense in which it would have been understood in $1867 . .^{18}$ Hogg describes how Canadian society has undergone profound changes since 1867 . The Constitution has been amended very infrequently and yet the words employed by the framers continue to inform the governance of this much changed nation. ${ }^{19}$

Justice Dickson reinforces this fundamental difference between ordinary and constitutional statutes in the context of the Charter:

A statute defined present rights and obligations. It is easily enacted and as easily repealed. A constitution, by contrast, is dratted with an eye to the future. Its function is to provide a continuing framework for the legitimate exercise of governmental power.... Once enacted, its provisions cannot easily be repealed or amended. It must therefore be capable of growth and development over time to meet new social, political and historical realities often unimagined by its framers. ${ }^{20}$

Constitutional documents must be interpreted generously, keeping in mind the purpose and fundamental character of such documents. Unduly restrictive interpretations would undermine the purpose and intent of constitutional documents and frustrate the intention of the framers.

16. Ibid. at 136-37.

$17 \quad$ Ibid. at 135 .

ix See P. Hogg, Constitutional Law of Canada, looseleaf (Scarborough: Carswell, 1997) at 15.9(f).

1.) Ibid.

21 Hunter v. Southam Inc., [1984] 2 S.C.R. 145 at 155 [hereinafter Hunter]. 
The jurisprudence has described the nature of constitutional documents and has articulated the manner in which the nature of the documents informs their interpretation. Constitutional documents were intended to inform the governance of the country for a long time. The words employed in constitutional documents are general in nature and ambiguous by definition. It is the presumption of generality and ambiguity that enables progressive interpretation and ensures that constitutional documents will be able to adapt to a changing nation.

It is suggested that Pitfield J.'s analysis errs in concluding that a finding of ambiguity is a prerequisite to the applicability of the doctrine of progressive interpretation. Ambiguity is part of the underlying nature of these documents that arises from the intention of the framers. Ambiguity is not a prerequisite to the broad and liberal construction of any term.

\section{MARriage Defined? - HydE V. HYDE AND WOODMANSEE}

Should Pitfield J.'s approach to constitutional interpretation be a supportable one, $H y d e^{21}$ did not articulate an unambiguous definition of marriage as of 1866 . First, the comment in Hyde, considered by Pitfield J. to be dispositive, was clearly obiter. Second, the definition offered in Hyde did not attempt to provide a definitive and timeless statement of marriage. Finally, the enactment of the Constitution Act, 1867 itself demonstrates that the framers of the constitution did not subscribe to this definition.

In Hyde a husband petitioned for dissolution of his marriage on the ground of adultery. The petitioner was a Mormon and had been married to the respondent while living in Salt Lake City, Utah. After several years of cohabitation the petitioner was sent to the Sandwich Islands as a missionary. He went, leaving his wife and children in Utah. During his tenure in the Sandwich Islands the petitioner renounced Mormonism and began to preach against the faith. He was excommunicated and pronounced by the Mormon church to be divorced from his wife. The wife remarried in accordance with the tenets of that faith.

Justice Wilde declined to grant the relief requested. He found that persons united in a polygamous marriage could not be considered husband and wife in the sense in which these words must be interpreted in the Divorce Act. The court, he concluded, could not properly exercise any jurisdiction over the couple in the circumstances. The oft quoted passage in Hyde is:

I conceive that marriage, as understood in Christendom, may for this purpose be defined as the voluntary union for life of one man and one woman, to the exclusion of all others. ${ }^{22}$

Justice Wilde then quickly acknowledges that the definition is limited in its application: 
There are no doubt countries peopled by a large selection of the human race in which men and women do not live or cohabit together upon these terms - countries in which this Institution and status are not known. In such parts the men take to themselves several women, whom they jealously guard from the rest of the world, and whose number is limited only by consideration of material means. ${ }^{23}$

The ratio in Hyde clearly dealt with the requirement under British law that there be no more than two partners in any marriage. Multiplicity of marital partners was incompatible with the redress contained in the Divorce Act of the day. The ratio of the decision did not involve heterosexuality. Further, to the extent that Wilde J. had decided to declare in obiter a definition of marriage, he set himself the limited task only of defining a "Christian" marriage, as understood in that place and at that time. He expressly acknowledged that other traditions differ in their constituents. In addition to this limitation, a closer look at the definition demonstrates other manners in which Hyde cannot be considered to have articulated a conclusive definition of "marriage" in the context of 1866 (or 1867) Canada.

\section{A. "The Voluntary UniON"}

Justice Wilde describes marriage as a "voluntary" union. Clearly cultures and traditions extant both before and after the decision in Hyde do not include voluntarism as an essential element. Justice Pitfield's analysis would suggest that Parliament would have no legislative authority under s. 91, short of a constitutional amendment, to legislate in respect of non-voluntary unions such as arranged marriages. Further, even where voluntariness is thought to be a feature of marriage, the theory does not always reflect the reality:

In theory, the individual is free to choose whether to marry or not to marry. In practice, however, the reality may be otherwise.... The sanction of the union by the state through civil marriage cannot always be obtained. The law; the reluctance of one's partner to marry; financial, religious or social constraints - these factors and others commonly function to prevent partners who otherwise operate as a family unit from formally marrying. In short, marital status often lies beyond the individual's effective control. ${ }^{24}$

\section{B. "TO THE EXCLUSION OF ALL OTHERS"}

Monogamy is identified as an essential and defining attribute of marriage. While polygamous marriages are prohibited under Canadian law, monogamy is not a definitional attribute. Adultery is a ground of divorce under the Divorce Act. ${ }^{25}$ Adultery is, however, a ground available only at the election of the wronged spouse and does not operate to invalidate a marriage. Should the wronged spouse prefer to abide the indiscretion of a spouse, neither the state nor a third party has the power nor the authority to insist otherwise.

\footnotetext{
$23 \quad$ Ibid.

24 Miron v. Trudel, [1995] 2 S.C.R. 418 at 749, McLachlin J. (as she then was) [hereinafter Miron].

is $\quad$ R.S.C. 1985 (2d Supp.), c. 3, s. 8.
} 


\section{C. "FOR LIFE"}

Hyde includes as an element of marriage that marriage is "for life." This attribute could not have been included in the minds of the framers of the Constitution Act, 1867. Section 91(26) confers legislative power not just in relation to "marriage." The section confers legislative power in relation to "marriage and divorce." Given the articulation in Hyde, the concept of divorce is antithetical to that of marriage. In composing the head of power the framers clearly abrogated the Hyde definition.

\section{HYDE - CONCLUSION}

The decision in Hyde did not unambiguously define "marriage" at common law or within the collective consciousness of the citizenry at 1867 , and I submit that Pitfield J. erred in so finding. Little of the definition in Hyde survived beyond the Christendom of England, beyond the religious and cultural traditions of others, and beyond the Constitution Act, 1867 itself. The Hyde formulation might resonate in the sentimental consciousness of marriage, but it does not articulate its legal essence.

Rather than find that marriage had not been defined in 1867 and proceed to a further interpretive analysis, Pitfield J. finds a constituent alive in the rubble - heterosexuality. In support of his conclusion that heterosexuality is an essential criterion of marriage, two more considerations are offered: the capacity to procreate and the requirement of consummation as defined in the law. ${ }^{26}$

Procreation is not, however, a requirement of a marital union. Persons of the opposite sex may marry with very few restrictions. Marital partners do not have to prove fecundity as a prerequisite to marriage, and marriages are not annulled if they do not produce children. In Baxter v. Baxter ${ }^{27}$ a marriage was found to be valid even though the couple used contraceptive devices consistently. Neither is consummation an unavoidable requirement of a valid marriage. In Foster v. Foster ${ }^{28}$ a marriage was found to be valid despite a lack of consummation where the marital motivation of the parties was companionship and not procreation.

\section{Formulating an INTERPRETIVe APPROACH to MarRiage}

The question remaining then is how "marriage" should properly be interpreted. The jurisprudence prescribes the doctrine of progressive interpretation, but it also imparts a caution. Constitutional documents are to be given a large and liberal interpretation, but the expansion of their terms is not without limit. The living tree is capable of growth and expansion, but only "within its natural limits." 29

Supra note 1 at paras. 85,94 .

[1948] A.C. 274.

[1953] 2 D.L.R. 318.

Supra note 11 at 136. 
Guidance for the analysis can be found in Edwards. When interpreting a term employed in a constitutional document, a court should consider the internal evidence of the Act itself: "[T]he question is not what may be supposed to have been intended, but what has been said." ${ }^{30}$ Section 91 does not on its face define marriage, include the definition of "marriage" espoused in Hyde, or expressly limit legislative authority to the matter of "heterosexual marriage." The express language of the statute does not provide any definitive direction, and another comment in Edwards commends itself to the discussion:

The word "person." ... may include members of both sexes, and to those who ask why the word should include females, the obvious answer is why should it not? In these circumstances the burden is upon those who deny that the word includes women to make out their case. ${ }^{31}$

\section{A. A Purposive and Functional ANAlysis}

The jurisprudence suggests that an essentialist or definitional approach is not an appropriate manner in which to interpret constitutional terms. A review of the manner in which other heads of power have been interpreted informs the construction of a process by which marriage is to be interpreted. The approach taken in the interpretation of other heads of power contained in the Constitution Act, 1867 - namely, "criminal law" and "banking" - demonstrate that the appropriate analysis is functional and purposive in nature.

\section{CRIMINAL LAW - AN EXAMPLE}

Parliament has the power, under s. 91(27) of the Constitution Act, 1867 to legislate in relation to the criminal law. This head of power has been judicially developed well beyond that which might have been understood as being "criminal" in 1867. One would suspect that citizens in 1867 may have been fairly well acquainted with the nature of the conduct enjoined by the criminal law of the day. The courts quickly declined, however, to freeze the interpretation of the term to that historic understanding.

Lord Atkin in Proprietary Articles Trade Ass' $n$ v. Canada (A.G.) $)^{32}$ identified that the term "criminal law" is "not confined to what was criminal by the law of England or of any Province in 1867." 33 The courts have continued to return to the meaning of criminal law and have interpreted this head of power expansively. In Reference Re Validity of $s$. 5(a) of Dairy Industry Act (Canada) ${ }^{34}$ Justice Rand listed some examples of the valid purposes of criminal law: "Public peace, order, security, health, morality: these are the ordinary though not exclusive ends served by [criminal] law." 35 In Reference $R e$ Firearms Act (Canada) ${ }^{36}$ Chief Justice McLachlin summarized the expansiveness of the interpretation of the term in the context of contemporary society:

Ibid. at 137.

Ibid. at 138 .

[1931] A.C. 310, 2 D.L.R. 1.

Ibid. at 324.

(1948), [1949] S.C.R. I.

lbid. at 50.

(2000), 82 Alta. L.R. (3d) 1. 
[Criminal law] finds its expression in a broad range of legislation. The Criminal Code is the quintessential federal enactment under its criminal jurisdiction, but it is not the only one. The Food and Drugs Act, the Hazardous Products Act, the Lord's Day Act, and the Tobacco Products Control Act have all be held to be valid exercises of the criminal law power. ${ }^{37}$

The interpretation of "criminal law" has developed into an inquiry of whether a law contains the elements of criminal purpose, prohibition, and penalty. With this interpretive approach focusing on the purpose and on the function of heads of power and legislation enacted therefrom, the criminal power is allowed to adapt to changes in Canadian society. Constitutional amendment need not precede such change.

\section{BANKING - ANOTHER EXAMPLE}

Section 91(15) confers to Parliament the power to legislate in relation to banking. As in the interpretation of "criminal law," the courts have not engaged in a preliminary analysis to determine whether banking had been unambiguously defined at 1867 , but rather have employed the doctrine of progressive interpretation.

Lord Watson, writing for the Privy Council in Tennant v. Union Bank of Canada, ${ }^{38}$ stated that the term "banking" was "wide enough to embrace every transaction coming within the legitimate business of a banker." ${ }^{39}$ Later decisions applied the principles of progressive interpretation precisely to this formulation. In Alberta (A.G.) v. Canada $(A . G .)^{40}$ the Privy Council applied the progressive interpretation doctrine not just to "banking" but to the term "legitimate business of a banker."

The doctrine of progressive interpretation is properly employed not just to interpret the markers chosen by the framers of the constitution. It also serves as a tool for expanding and adapting the very interpretation of those terms in a manner that can accommodate the realities of a changing society.

\section{B. THE CHARTER - ANOTHER CONSIDERATION}

The interpretation of criminal law and banking suggests that the proper form of analysis for interpreting "marriage" is one focused on purpose and function. The precise contours of the form that this functional and purposive approach should take must be informed by another constitutional document - the Charter.

Justice Pitfield points out that the Charter cannot be used to override the terms of other constitutional documents. ${ }^{41}$ While the Charter will not override provisions contained in

\footnotetext{
$37 \quad$ Ibid. at 18.

38 [1894] A.C. 31 .

39) Ibid. at 46 .

40 [1947] A.C. 503, 4 D.L.R. 1.

$4 \quad$ Supra note 1 at para. 123.
} 
other constitutional documents, such other documents must be interpreted in a manner consistent with Charter values. ${ }^{42}$

The Charter is part of the constitutional fabric of Canadian society. Justice Dickson described in Hunter ${ }^{43}$ that the function of a constitution, when joined by a charter of rights, is "for the unremitting protection of individual rights and liberties." 44 One of the Charter values that must, in my view, inform the present analysis is that of equality in s. 15(1). The purpose of this section is "the promotion of a society in which all are secure in the knowledge that they are recognized at law as human beings equally deserving of concern, respect and consideration." 45

A development in the jurisprudence under s. 15 of the Charter, seen as critical to the vindication of equality values, is the rejection of formalistic analytical approaches. Justice Cory, writing for the plurality in Egan, recalls a fundamental flaw contained in the "similarly situated test" considered in Andrews: "the so-called 'similarly situated test' was rejected on the grounds that its reasoning was unduly formalistic and circular: it uncritically accepted the distinction drawn by the questioned statute and then proceeded to rely upon that same categorization in order to justify the distinction drawn." 46

Justice Cory recognizes that in determining whether particular facts demonstrate equality or inequality, one must necessarily undertake a form of comparative analysis. He notes however that it is important to view the effects of a distinction and the larger social, political and legal context of that distinction. It is not appropriate for a distinction to be accepted uncritically.

In Miron ${ }^{47}$ McLachlin J. (as she then was) also identifies the dangers of unduly formalistic reasoning and describes this manner of analysis as circular and as an arid approach to Charter values. She illustrates the point by taking issue with the analysis employed by LaForest J. in Egan, a case considering the constitutionality of the exclusion of same-sex couples from provisions contained in the Old Age Security Act: ${ }^{48}$

LaForest, J. characterizes the functional value of the legislation as meeting the need to support married couples who are elderly. Because, in his view, marriage is "firmly anchored in the biological and social realities that heterosexual couples have the unique ability to procreate"... Parliament may use the relevant ground of sexual orientation as a basis for distinguishing who should receive benefits under the Act. By defining the legislative aim in terms of the alleged discriminatory ground, namely married couples, the relevance of the ground is assured. On the assumption - misplaced in my view - that this relevance suffices to negate discrimination, s. $15(1)$ is said to be met without examining the actual impact of the legislation on members of groups who may be disadvantaged by the distinction." 49

See M.(A.) v. Ryan, [1997] I S.C.R. 157.

Supra note 20.

Ibid. at 155.

Andrews v. Law Society (British Columbia), [1989] I S.C.R. 143 at 171.

Egan v. Canada, [1995] 2 S.C.R. 513 at para. 133.

Supra note 24.

R.S.C. 1970 , c. O-6.

Supra note 24 at 743. 
Justice McLachlin concludes that "[t]he only way to break out of the logical circle is to examine the actual impact of the distinction on members of the targeted group." $\$$

It is respectfully submitted that Pitfield J. employed a type of formalistic analysis. The impugned distinction was between same-sex and opposite-sex marriage. The purpose of the head of power was described as the conferral of legislative power in relation to opposite-sex marriage only. The purpose of the provision was defined in a manner that included the impugned distinction, and the result of the analysis achieved was without any apprehension or consideration of the effect of the conclusion.

The consequence of the analysis is to relegate the intimate relationships of one class of persons - a class subject to historic disadvantage in Canadian society, wholly outside of marriage - which is a profoundly important feature of Canadian society. Justice McLachlin writes in Miron of the significance of marital status: "[m]arital status touches the essential dignity and worth of the individual.... [s]pecifically, it touches the individual's freedom to live life with the mate of one's choice in the fashion of one's choice. This is a matter of defining importance to individuals." 51

The intimate relationships of same-sex couples is determined to lie outside of the ambit of marriage, as defined in the constituting documents of the nation, and beyond the protections of the Charter. Justice Pitfield concludes that same-sex marriage can be legislated only after a process of constitutional amendment. Creating this extraordinary procedural requirement sends a powerful message that gay and lesbian Canadians and their relationships are fundamentally alien to Canadian society and belies the vaulted purposes of the Constitution as expressed by Dickson J.

To allow formalistic analysis a home in one constitutional document when it has been rejected in another is not consistent with constitutional jurisprudence, nor is it consistent with the goal of promoting a society in which all are secure in the knowledge that they are equally deserving of respect and consideration. I would suggest that a proper approach to the interpretation of "marriage" must not include heterosexuality as a defining and an a priori element of the analysis.

\section{Interpreting Marriage - A Proposal}

How then should "marriage" be interpreted in a manner consistent with the doctrine of progressive interpretation? What might a purposeful, functional analysis, consistent with Charter principles and sensitive to contemporary social reality look like?

Such an analysis might take as a starting point an observation made in Hyde. Justice Wilde acknowledges that marriage is more than a contractual relationship. It is a status to which various legal incidents attach: 
Marriage has been well said to be something more than a contract, either religious or civil - to be an Institution. It creates mutual rights and obligations, as all contracts do, but beyond that it confers a status.... [T] he laws ... throw about that status a variety of legal incidents during the lives of the parties and induce definite rights upon their offspring. 52

Section 91(26) confers to Parliament the power to legislate in relation to marital capacity. The head of power might be described at least in part as conferring to Parliament the power of a gate keeper: the power to define the criteria by which some relationships are allowed entry to the legal status of marriage while others are denied. At the very least, Parliament must have, under s. 91(26), the power to chose from among a larger class of relationships that might be considered "marriage-like" and those members of the class that will be admitted entry to the legal status of marriage.

The task, then, is to create a method of analysis by which "marriage-like" relationships might be described in a manner that is functional, consistent with Charter values, and sensitive to contemporary social reality.

I would commend the approach taken by Kurisko D.C.J. in Molodowich v. Penttinen ${ }^{33}$ as a helpful analysis of the features of "marriage-like" relationships. Judge Kurisko considered the criteria by which a couple, a heterosexual couple on the facts of that case, could be described as having "lived together in a conjugal relationship" and thus as "spouses" under the Family Law Reform Act. ${ }^{54}$ After reviewing numerous decisions Kurisko D.C.J. concluded that conjugal relationships, that is spouses, shared some or all of the following features:

\section{Sheller:}

(a) Did the parties live under the same roof?

(b) What were the sleeping arrangements?

(c) Did anyone else occupy or share the available accommodation?

2. Sexual and Personal Behavior:

(a) Did the parties have sexual relations? If not, why not?

(b) Did they maintain an attitude of fidelity to each other?

(c) What were their feelings toward each other?

(d) Did they communicate on a personal level?

(e) Did they eat their meals together?

(f) What, if anything, did they do to assist each other with problems or during illness?

(g) Did they buy gifts for each other on special occasions?

3. Services:

What was the conduct and habit of the parties in relation to:
(a) preparation of meals;
(b) washing and mending clothes;
(c) shopping;
(d) household maintenance; and 
(e) any other domestic services?

4. Social:

(a) Did they participate together or separately in neighbourhood and community activities?

(b) What was the relationship and conduct of each of them toward members of their respective families and how did such families behave towards the parties?

5. Societal:

(a) What was the attitude and conduct of the community toward each of them as a couple?

6. Support (economic):

(a) What were the financial arrangements between the parties regarding the provision of or contribution toward the necessaries of life (food, clothing, shelter, recreation, etc.)?

(b) What were the arrangements concerning the acquisition and ownership of property?

(c) Was there any special financial arrangement between them which both agreed would be deterninant of their overall relationship?

\section{Children}

What was the attitude and conduct of the parties concerning children? ${ }^{55}$

He concluded that in determining whether any pair of persons live in a conjugal or marriage-like relationship, these questions should be considered, keeping in mind that no single relationship is likely to display all of the enumerated features or to manifest each to the same degree.

The Supreme Court of Canada took this analysis one step further in $M$. v. H., ${ }^{56}$ a decision considering whether the exclusion of same-sex couples from spousal support provisions contained in the Family Law Act ${ }^{57}$ of Ontario violated the Charter. Justice Cory, writing for the majority, considered as a preliminary question whether same-sex couples could, as required in the impugned definition, be "conjugal" in nature.

Justice Cory noted that "it might be argued that same-sex couples do not live together in 'conjugal' relationships, in the sense that they cannot 'hold themselves out' as husband and wife." ${ }^{58} \mathrm{He}$ then went on to consider with approval the criteria identified in Molodowich and found that same-sex couples share with opposite-sex couples many "conjugal" characteristics:

In order to come within the definition [of conjugal relationship], neither opposite-sex couples nor samesex couples are required to fit precisely the traditional marital model to demonstrate that the relationship is "conjugal." Certainly an opposite-sex couple may, after many years together, be considered to be in a conjugal relationship although they have neither children nor sexual relations. Obviously the weight to be accorded the various elements or factors to be considered in determining whether an opposite-sex couple is in a conjugal relationship will vary widely and almost infinitely. The same must hold true of same-sex couples. Courts have wisely determined that the approach to determining whether a relationship is conjugal must be flexible. This must be so, for the relationships of all couples will vary widely. ${ }^{59}$

Supra note 53 at $381-82$.

[1999] 2 S.C.R. 3, 171 D.L.R. (4th) 577.

R.S.O. 1990, c. F-3.

Supra note 56 at 615 .

Ibid. at 616 . 
Justice Cory concluded that "there is nothing to suggest that same-sex couples do not meet the legal definition of 'conjugal."' 60 This analysis would suggest that same sex couples and opposite sex couples share the same functional elements and are equally able to be conjugal or marriage-like in quality. Employing this analysis to identify the class of relationships over which Parliament has legislative power in relation to marital capacity suggests that Parliament does have capacity to legislate in respect of same-sex marriage.

\section{CONCLUSION}

In the result, the Constitution $\mathrm{Act}, 1867$ does not serve to insulate any prohibition against same-sex marriage from Charter redress. Parliament can legislate in relation to such marriages and can correct any violation identified upon a Charter analysis. The fate of the petition lies squarely within the four corners of the Charter, where this issue, I submit, belongs. 